Arhe XVI, 32/2019

UDK 179

DOI https://doi.org/10.19090/arhe.2019.32.115-122

Originalni naučni rad

Original Scientific Article

JAGODA DRLJAČA ${ }^{1}$

Institut društvenih nauka u Beogradu, Centar za pravna istraživanja

\title{
TRANSPLANTACIJA ORGANA U SVETLU NOVOG ZAKONA: PRAVNE I ETIČKE NEDOUMICE
}

Sažetak: Novi Zakon o presađivanju organa doneo je brojne nedoumice kako stručnoj, tako i laičkoj javnosti vezano za prihvatanje opt out modela, registra donora, lica koja dokidaju doslednu primenu principa pretpostavljene saglasnosti. Autor pokušava da odgovori na pravne i etičke nedoslednosti.

Ključne reči: Zakon o presađivanju ljudskih organa, donorstvo, saglasnost, etika

Leon Kas (Leon R. Kass) i Aleksander Kapron (Aleksander M. Capron) smatraju se rodonačelnicima koncepcije po kojoj se moždana smrt poistovećuje sa ljudskom smrću. Godine 1972. definisali su moždanu smrt kao stanje identično tradicionalnom poimanju smrti gde odsustvuje spontani rad srca, kao i disanja. Za razliku od tradicionalnog shvatanja, danas se napretkom medicine ta odsutnost može nadomestiti na veštački način reanimacijom. Tvorci su prihvatanja koncepcije smrti celog mozga. Britanci prvi put 1976. godine artikulišu koncept po kome je moždana smrt prihvaćena kao smrt celog organizma, gde se ne radi o smrti čitavog mozga, nego smrti moždanog debla. Smrću moždanog debla nastupa smrt čitavog mozga koja je prouzrokovana fiziološkim prestankom većine vitalnih funkcija. Prestankom funkcionisanja neokorteksa, moždane kore, ne dolazi do smrti moždanog stabla, tj. čitavog mozga, ali dolazi do uništenja neuro-fiziološke baze. Tako nastaje smrt svih karakteristika osobe.

\footnotetext{
${ }^{1}$ E-mail adresa autorke: jagoda.drljaca@yahoo.com
} 
Komitet Harvardske medicinske škole je 1968. godine utvrdio šest kriterjuma moždane smrti:

1. Postojanje duboke kome bez reakcije na bolne nadražaje

2. Potpuno odsustvo spontanog disanja

3. Odsustvo refleksa moždanog stabla

4. Odsustvo spinalnih refleksa

5. Odsustvo postularne aktivnosti kao što je decerebracija

6. Ravan elektroencefalografski zapis.

Godine 1971. utvrđuju se takozvani Minesota kriterijumi moždane smrti. Oni su istovetni Harvardskim, osim u zahtevu za ravnim elektroencefalografskim zapisom (po ovim kriterijima EEG ne mora pokazati potpunu ravan, iako je u pitanju ireverzibilno oštećenje mozga).

Finska je 1971. godine bila prva zemlja koja je u svoje zakonodavstvo uvela pojam moždane smrti. To je značilo revoluciju u transplantacionoj medicini gde se eksplantiraju te transplantiraju još uvek prokrvljeni organi pa su samim tim efikasnost i prognoza same transplantacije, kao i budućeg života transplantiranog umnogome poboljšana.

Transplantacija se definiše kao operacija kojom se presađuje deo tkiva ili organ $\mathrm{s}$ istog ili drugog organizma. Autotransplantacija podrazumeva uzimanje transplantata $\mathrm{s}$ istog pacijenta i presađivanje tamo gde je potrebno (primer autotransplantacije je premošćivanje krvnih sudova na srcu, tzv. bajpas gde se za operaciju koriste graftovi samog pacijenta), homotransplantacije (transplantat se uzima s drugog davaoca) ili ksenotransplantacije gde se transplantat dobija $\mathrm{s}$ različite vrste (upotreba svinjskog zaliska u operaciji srčanih zalistaka kod čoveka). Savremena transplantaciona medicina dospela je do mogućnosti transplantacije bubrega, srca, pluća, pankreasa, kože, kostiju, nerava, koštane srži, jetre etc., izuzimajući transplantaciju parnih organa, delova jetre i koštane srži. Jedan od najvećih problema koji se javlja u transplantacionoj medicini je problem donacije organa, tj. davanje saglasnosti. Od države do države, razlikuju se tumačenja pitanja o neophodnosti davanja pisane, informisane saglasnosti za davanje organa 
drugome ili je dozvoljeno eksplantirati organ tamo gde je izostala registrovana zabrana uzimanja organa nakon moždane smrti. ${ }^{2}$ Pravna regulativa u oblasti transplantacije ljudskih organa može se posmatrati s nacionalnog i međunarodnog aspekta. Republika Srbija je potpisnica Evropske konvencije o ljudskim pravima i biomedicini. Konvencija je sačinjena u Ovijedu 4.4.1997. godine, a njena ratifikacija je okončana 15.12.2010. godine, dok je pravno obavezujućom postala u junu 2011. godine. Preambula Konvencije - pozivajući se na prethodno potpisane Konvencije, deklaracije i sporazume Ujedinjenih nacija, Međunarodnih paktova i Evropskih povelja, a s obzirom na neumitnost ubrzanog razvoja biologije, medicine, genetike koji je evidentan - štiti pravo i dostojanstvo te integritet ljudskog bića, a u pogledu primene biologije i medicine:

Član 2. Konvencije iz Ovijeda daje prednost interesu i dobrobiti ljudskog bića pred interesima društva i nauke.

Član 3. ukazuje na potrebu osiguranja pravičnog pristupa zdravstvenoj zaštiti odgovarajućeg kvaliteta.

Član 5. obavezuje zemlje potpisnice na informisani i slobodan pristanak lica nad kojima se vrši zahvat zdravstvene prirode. Lice mora biti upoznato sa svim posledicama i mogućim rizicima zahvata, te mora imati mogućnost odustajanja od date saglasnosti.

Član 6. štiti maloletna i lica koja nisu sposobna da daju svoj pristanak na zahvat. Zahvat se može izvršiti samo u njihovu korist, a uz odobrenje zastupnika, tj. organa koje predviđa zakon.

Govoriti o moždanoj smrti, dijagnozi ključnoj u transplantacionoj medicini, moguće je i mora se s dva stanovišta. Prvo je stanovište umirućeg pacijenta kome treba, poštujući Ustav, međunarodne Konvencije, zakone omogućiti pravo na lečenje koje bi moralo imati za cilj odlaganje smrti. Drugo stanovište počiva na isticanju interesa savremene transplantacione medicine kojoj je primarno da postavljanje dijagnoze moždane smrti bude što ranije, te da posledično do eksplantacije organa dođe što je moguće ranije, a samim tim do izvesnije uspešnosti same transplantacije organa.

\footnotetext{
${ }^{2}$ Videti više: Radišić, Jakov (2004), Medicinsko pravo, Nomos, Beograd, str. 107-116.
} 
Osim razlike $\mathrm{u}$ dijagnostici moždane smrti, postoje razlike i $\mathrm{u}$ zakonskoj regulativi među državama kada je u pitanju eksplantacija te transplantacija organa nakon smrti te osobe. Koncept prihvaćen u Danskoj, Nemačkoj, Holandiji, Švajcarskoj, Australiji i SAD bazira se na davanju izričite saglasnosti (tzv. koncept opt in). Tu je, osim izričite saglasnosti za uzimanje organa s tela umrlog radi transplantacije, moguće dobiti saglasnost i od njegovih najbližih, zakonom definisanih srodnika. Koncept počiva na potpunoj informisanosti i dobrovoljnosti koja je iskazana još za života potencijalnog davaoca organa (donora). U konceptu informisane saglasnosti za transplantaciju uvažava se činjenica potpune autonomije i poštovanja volje osobe kako za života, tako i u smrti. $^{3}$

Koncepcija koju prihvata većina zemalja Evropske unije - poput Italije, Francuske, Španije, Belgije, Poljske, Austrije, Švedske, Norveške i Hrvatske - vodi se načelom pretpostavljene saglasnosti za transplantaciju. Eksplantacija te transplantacija organa s umrle osobe neće biti izvršena samo ako se pacijent za života izjasnio i ubeležio u registar protivnika transplantacije. Taj stav sledi iz koncepcija opt out: dozvoljeno je ono što nije izričito zabranjeno!

Japan ima vrlo specifičan koncept moždane smrti i njenog proglašenja, vezano za transplantaciju organa. U Japanu se davalac organa o donorstvu izjašnjava za života i samo u tom slučaju, a u svrhu transplantacije organa se proglašava moždana smrt. U svim drugim slučajevima kod stanovnika Japana smatra se da smrt nastupa kad srce prestane da kuca. Japanska je specifika da porodica, uprkos pismeno datoj saglasnosti o donorstvu, ima legitimno pravo da odbije dati dopuštenje za eksplantacijom organa svog preminulog člana.

Uprkos nespornoj supremaciji nad Zapadom u elementima tehnologije, obrazovanja i nekim drugim područjima života, japanski stav o proglašenju moždane smrti - vezan za transplantaciju organa - svoje poreklo dobrim delom ima u religijskim doktrinama, kao i etičkim

\footnotetext{
${ }^{3}$ Slično o tome: Vesna Klajn Tatić (2007), „Uzimanje organa od umrlih davalaca - medicinski, etički i pravni problem", Zbornik radova Pravnog fakulteta, Novi Sad, Vol. XLI, br. 3., str. 271-287.
} 
shvatanjima koja su drugačija od zapadnih. Predstavnici šinto religije, budizma i konfučijanstva, kao dominantnih religija u Japanu, ne pokazuju blagonaklon odnos prema transplantaciji organa. ${ }^{4}$

Prva transplantacija bubrega izvedena je 1954. god. u SAD, a prva transplantacija srca nakon moždane smrti davaoca 1967. god. u Južnoafričkoj republici od strane doktora Kristijana Barnarda (Christiaan Neethling Barnard) i njegovog tima. ${ }^{5}$

Zakon o presađivanju ljudskih organa jula usvojen je 2018. godine nakon brojnih polemika i kontroverzi. Uzimanje organa s živoga davaoca regulisano je na istovetan način kao i starim zakonom: punoletno i poslovno sposobno lice uz pismeno dati pristanak nakon informisanja o rizicima po zdravlje i ukoliko ne postoji značajan rizik po njegovo zdravlje.

Uzimanje organa s umrlog lica (kadavera): Član 23.: Uslovi za darivanje organa umrlog lica.

Ljudski organi s umrlog lica mogu se uzeti radi presađivanja ukoliko se punoletni poslovno sposoban davalac pre smrti tome nije usmeno ili u pismenom obliku za života protivio, odnosno, ukoliko se tome u trenutku smrti nije izričito usprotivio roditelj, supružnik, vanbračni partner ili punoletno dete umrlog. Novim Zakonom o presađivanju ljudskih organa (Službeni Glasnik RS 57/2018.) na prvi pogled fokus je stavljen na prelazak na opt out model, tzv. pretpostavljenu saglasnost, ali $\mathrm{s}$ brojnim protivurečnostima i nedorečenošću. Lice će se u trenutku smrti smatrati donorom, ako se tome nije tokom života izričito usprotivilo. U Zakonu registar se ne spominje. Očigledno, zakonodavac je odustao od namere da u potpunosti prihvati opt out model. Model pretpostavljene saglasnosti nije dosledno proveden, jer Zakon dopušta članovima porodice (roditelj, supružnik, vanbračni partner, punoletna deca) da se nakon smrti lica usprotive

${ }^{4}$ Vidi: S. Weyrauch (1999), ,Acceptance of Whole Brain Death Criteria for Determination of Death: A Comparative Analysis of the United States and Japan", Pacific Basin Law Journal 17 (1/1999) str. 91-123.

${ }^{5}$ Videti šire: J. Samardžić, D. Lovrić, D. Miličić (2011), „Transplantacija srca indikacije, kontraindikacije i dugoročno liječenje transplantiranih bolesnika", u Medix, ožujak - travanj br. 92/93, str. 160-164. 
doniranju, jer nezavisno od njegove volje, organi se ne mogu koristiti za transplantaciju.

Dosledna primena opt out modela podrazumeva isključivo obaveštavanje članova porodice o nameri eksplantacije organa, a ne dopuštanje da porodica anulira pretpostavljenu ili izričitu volju umrlog da bude donor. Zakon ne razjašnjava šta biva s već postojećim donorskim karticama i registrom donora koje je predviđao raniji Zakon.

Među državama članicama Evropske unije postoje koncepti pribavljanja organa u svrhu transplantacije. Koncept tzv. jakog pristanka dopušta lekarima da nezavisno od volje samog donora ili njegove porodice eksplantiraju sve upotrebljive organe. Sistem tzv. mekog pristanka zahteva upis u registar lica koja ne dozvoljavaju eksplantaciju svojih organa nakon smrti, čime odriču sebi pravo da budu transplantirani, ako im transplantacija bude potrebna.

Napretkom medicine usložnjavaju se brojna pravna, ali i etička pitanja na polju medicinske etike, što ukazuje na važnost nadzora medicinske delatnosti. Etička načela su a priori postavljena kao smernice delovanja pri lekarskom odlučivanju. Teološka percepcija etike i morala postavlja kriterije ljudskog moralnog delanja u sistemu očekivanja večne nagrade ili kazne. Takav princip ukida autonomiju volje. Nasuprot tome, Kant smatra da pojam morala mora počivati na ,principu beskrajnog individualnog prava na slobodno djelanje u svim područjima djelanja. Njegova je osnova u pravu posebnosti svake ljudske ličnosti da se ispolji u svojoj slobodi u svakom području djelanja (pravo, politika i ekonomija).“6

Vrednost moralnog delanja, po Kantu, nije u njegovim $u$ ciljevima, nego u motivima: „Princip slobode je - u svom najvišem ontološkom i antropološkom određenju - princip morala.“7 Princip moralnog delovanja je neodvojiv od slobode. Ona je princip, sadržaj i svrha morala. Etika proizlazi iz moralnih dilema, od mogućnosti moralnog izbora između dve ili više mogućnosti. Teorija morala traga za odgovorom na pitanje kako ispravno delati na moralno prihvatljiv način.

\footnotetext{
${ }^{6}$ Perović, Milenko A. (2013), Filozofija morala, Cenzura, Novi Sad, str. 178.

${ }^{7}$ Isto, str. 177.
} 
Deontološka etika s Kantom kao svojim najistaknutijim predstavnikom smatra da je ključ u autonomiji volje.

Transplantacija organa je visokorizičan $i$ istovremeno neophodan postupak koji u sebi nosi pitanja ličnog i telesnog integriteta stavova prema umrlima, delovima tela, darivanju. Za donora, odstranjenje organa je visokorizična, neterapeutska intervencija u kojoj rizici nisu srazmerni koristi za pacijenta. Nasuprot njemu, transplantiranom je transplantacija neophodna za život. Jedno od osnovnih načela medicinske etike je načelo: Ne naškoditi; Ne povrediti (lat. primum nil nocere)! Savremena medicina u ovakvim situacijama mora poštovati autonomiju volje donora. Biti davalac organa je lično pravo. Mogućnost transplantacije zavisi isključivo od volje davaoca da učini poklon drugom licu u dobroj veri da će mu taj poklon doneti dobro. Morala bi se prihvatiti činjenica da niko nema pravo na organe drugog čoveka, da darivanje organa nije građanska dužnost nego isključivo altruistična odluka proistekla iz svesti o dobru drugoga.

\section{LITERATURA}

Klajn Tatić, Vesna (2007), „Uzimanje organa od umrlih davalaca - medicinski, etički i pravni problem", Zbornik radova Pravnog fakulteta, Novi Sad, Vol. XLI, br. 3, str. 271-287.

Perović, Milenko A. (2001), Etika, Grafomedia, Novi Sad.

Perović, Milenko A. (2013), Filozofija morala, Cenzura, Novi Sad.

Radišić, Jakov (2004), Medicinsko pravo, Nomos, Beograd.

Samardžić, Jure/Lovrić, Daniel/Miličić, Davor (2011), „Transplantacija srca indikacije, kontraindikacije i dugoročno liječenje transplantiranih bolesnika", u Medix, ožujak - travanj br. 92/93, str. 160-164.

Weyrauch, Samantha (1999), „Acceptance of Whole Brain Death Criteria for Determination of Death: A Comparative Analysis of the United States and Japan", Pacific Basin Law Journal 17 (1/1999) str. 91-123.

Zakon o transplantaciji organa, „Službeni glasnik RS”, broj 72, 2009.

Zakon o presađivanju ljudskih organa, „Službeni glasnik RS”, broj 57, 2018. 
JAGODA DRLJAČA

Institute of Social Sciences Belgrade, Centre for Legal Research

\title{
ORGAN TRANSPLANTATION IN THE LIGHT OF THE NEW LAW: LEGAL AND ETHICAL DILEMMAS
}

\begin{abstract}
The new Law on Transplantation of Organs brought numerous dilemmas to the professional as well as to the lay audience concerning the adoption of opt-out model, registry of donors, persons who abolish the consistent application of the principle of presumed consent. The author tries to respond to the legal and ethical inconsequences.
\end{abstract}

Keywords: The Law on Transplantation of Organs, organ donation, consent, ethics

Primljeno: 31.8.2019.

Prihvaćeno: 2.11.2019. 